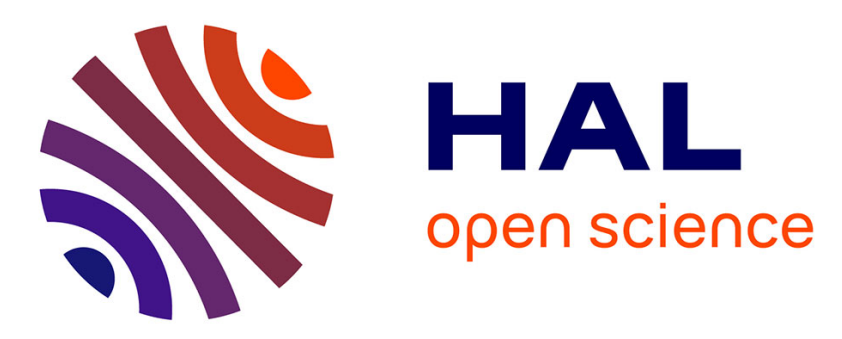

\title{
Interdisciplinary research on the heritage of housing complexes in France (1945-75)
}

Raphaël Labrunye, Gauthier Bolle, Karim El Alami, Ignacio Requena-Ruiz, Daniel Siret

\section{- To cite this version:}

Raphaël Labrunye, Gauthier Bolle, Karim El Alami, Ignacio Requena-Ruiz, Daniel Siret. Interdisciplinary research on the heritage of housing complexes in France (1945-75). 6th International Congress on Construction History. Building Knowledge, Constructing Histories, Jul 2018, Bruxelles, Belgium. pp.837-842. halshs-01842078

\section{HAL Id: halshs-01842078 \\ https://shs.hal.science/halshs-01842078}

Submitted on 20 Aug 2018

HAL is a multi-disciplinary open access archive for the deposit and dissemination of scientific research documents, whether they are published or not. The documents may come from teaching and research institutions in France or abroad, or from public or private research centers.
L'archive ouverte pluridisciplinaire HAL, est destinée au dépôt et à la diffusion de documents scientifiques de niveau recherche, publiés ou non, émanant des établissements d'enseignement et de recherche français ou étrangers, des laboratoires publics ou privés.

\section{(c)(1)}

Distributed under a Creative Commons Attribution| 4.0 International License 


\title{
Interdisciplinary research on the heritage of housing complexes in France (1945-75)
}

\begin{abstract}
AUTHORS: Raphaël LABRUNYE ${ }^{1}$, Gauthier BOLLE ${ }^{2}$, Karim EL ALAMI, Ignacio REQUENA \& Daniel SIRET ${ }^{3}$.
ABSTRACT: This paper presents the methodology of the research program "SMART FRENCH, collective housing of the second part of the twentieth century, through the prism of energy". Many energy renovation operations of this heritage are mostly carried out in the perspective of very heavy transformations, in particular by external thermal insulation. The aim of the research program is to appraise and rank the architectural, technical, historical or constructive value of these post-war housing complexes. The purpose is to build a database as exhaustive as possible on nearly 700 operations, published at the time of their construction and then to evaluate the initial environmental qualities of the projects in terms of integration into the landscape, solar orientation, spatial articulations, thermal inputs. This set of information will then be the subject of an analytical treatment to emphasize the most current situations and those that are considered obsolete in view of the contemporary demands.
\end{abstract}

Keywords: 20th century, France, Mass Housing, Renovation, Heritage.

\section{Introduction}

The main purpose of this research project is to build an in-depth knowledge of the stock of collective housing projects produced after the Second World War, with an operational focus. This heritage, built between 1949 and 1974, constituted nearly 20\% of housing in France. In the Greater Paris area, the collective dwellings produced during this period represent $26 \%$ of energy consumption and $31 \%$ of regional gas emissions. Victims of a global negative judgment, these groups have undergone since the $1980 \mathrm{~s}$ recurrent policies of majortransformations, particularly in the field of social housing, accentuated by the PNRU (National Program for Urban Renewal) and the so-called Grenelle de l'environment, a series of environmental laws voted in France in 2007-2009. Regulatory and financial measures have favored a generic thermal approach, through standardized calculation engines, by passing on new construction methods, themselves in question (Sidler 2007). Insulation from the outside is often handled by a solution applied on a large scale, reinforced by the recent decree on facade remodeling (Décret $\mathrm{n}^{\circ}$ 2016-711 du 30 mai 2016). The lack of a global environmental assessment is accompanied by explosive pathologies in several reports (RAGE 2012). However, recent work has a strong interest in having a detailed knowledge of each operation in order to find sustainable and financially balanced solutions (Graf et al. 2012). The question is how to study such a mass of buildings, without a generic and reductive approach nor a monographic and too limited one. Our main hypothesis is that these housings had been conceived with an environmental approach, even if it was not with our contemporary criteria. Combining historical and engineering sciences, we try to bring out relevant characteristics in the fields of design, urbanism, solar exposition or construction types. To manage this ambitious program, we have associated several researchers coming from seven graduate schools of architecture in France (Nantes, Rennes, Strasbourg, Bordeaux, Clermont-Ferrand, Rouen) and in Belgium (Vrije Universiteit Brussels).

\section{Between global and specific approach: using database}

Knowledge of the post-war housing estate stock remains, however, still limited by its mass. Since the "hard French" of Bruno Vayssière (1988), first militant synthesis book, some works tried to pursue this global perspective (Collectif 1995-1997, Bourillon et al. 2006). Others are situated in the fields of social and political histories (Le Goullon 2014) in the following works by Jean-Claude Croizé (2009), Danièle Voldman (1997), Annie Fourcaut and Frédéric Dufaux (2004). Some thematic works have been published with a specific focus on constructive innovations (Lambert \& Nègre 2009), landscapes (Blanchon 2010) or assembled concrete (Delemontey 2015). Recently, mainly monographic researches have been published, about an architect (Bolle 2017, Guillerm 2015), a specific project (Klein 2014, Gruet 2013), the SCIC owner, Société centrale

\footnotetext{
${ }^{I}$ Graduate School of Architecture of Bretagne, Rennes, France

${ }^{2}$ Graduate School of Architecture and Landscape of Bordeaux, Bordeaux, France

${ }^{3}$ Graduate School of Architecture of Nantes, Nantes, France
} 
immobilière de la Caisse des dépôts (Landauer 2010) and a SAE construction company, Société Auxiliaire d'Entreprises (Jambard 2008). Aside from our last work (Carrie \& Labrunye 2013, Siret 2013), not one has been oriented to operational issues or environmental questions.

The ambition of the study is to approach this mass production on a relevant scale, going beyond the two types of existing work: the case study that provides specific and non-reproducible responses and the generic approach that reduces this pro- duction to "heat sieves". It is therefore a question of elaborating a method of analysis of forms that goes beyond the typo-morphology, perfectly applicable to the plot and the islet, but incomplete on the scale of a land area of several hectares, and obsolete with the spread of construction systems throughout the country on a large scale. The aim is to identify recurrences or characteristic series of a large sample. The methods defined since the 1960s by the historian Pierre Chaunu under the name of "serial history" are one of the most appropriate methodological bases (Chaunu 1978). For a corpus such as the one we are proposing to study, that is to say, spread over a limited period of time, according to location criteria and a sampling of objects with relatively homogeneous characters (also delimited by criteria: economy, scales, materials on the one hand, geographical situations, societies, etc. on the other hand), the adoption of a serial method does not pose the problems which constitute its limits: temporal discontinuity, exceptionality of the object.

In fact, we have constituted our own database, by a systematic analysis of architectural journals published between 1944 and 1975. We have worked on the three major French journals: Architecture d'Aujourd'hui, Architecture Française and Technique et Architecture. The main idea is to concentrate our work on projects with architectural qualities that are necessary to save. Architectural journals do not ever have the monopoly of architectural qualities, but thanks to this method, we managed to assemble nearly 700 urban operations from the period. Then, we organized a database with the software File Maker Pro to collect all information available. The structure of the data- base is organized with five tables: Project/Article/ Advertising/Ensemble/Building. The first one is the most important, with all information on each project, identified with a specific code made by ARCHITECT-TOWN-YEAR. Each article or ad is linked to the table "Project" in this way. "Ensemble" is used to link operations built in several parts with several forms and construction system in the same site. "Building" is used to describe each building of each project. With such process, we can add new information throughout the whole process, new headings or new recordings according to the progress of the study. It is a way to pursue the using of the database after the end of the study, and the developing of items.

Then, the question is which indicators we have to consider as the characteristics of the projects. The objective is to revisit the historical knowledge of the period commonly and too easily referred to as the Trente Glorieuses. Literature on the subject, often the result of critics of modernity, generalizes it as a period without environmental design (Alexandroff 1982), while the post-crisis period following the oil crisis is seen as innovative (Bobette et al. 2007). The technical literature considers that between 1948 and 1974, all architectural production is obsolete (Collective 2011). However, this period is characterized by at least two phases, the first is an economic situation of shortage and an unstable political context, to which succeeds an unprecedented prosperity. The attention paid by the designers to the control of the ambiances and the architectural quality also seems to evolve very substantially. By collecting discourses from articles in the database, it appears that the lack of materials, which lasted until the end of the 1950s, promoted the search for economic devices such as the use of insulating lacunary materials. Production attests to a will and specific research regarding the qualities and functionality of housing, adapting the ideals originating from the Modern Movement to a singular historical, social and economic context. With the database, we can see how "preserving existing trees" is regularly present in the discourses of architects during the 1950s and completely disappears at the end of the 1960s. Insulation potential is mentioned at the first years of the period, in the continuity of modern theories.

\section{Environmental assessment}

These environmental qualities, however, go beyond the constructive aspect of the building envelope. One of the major characteristics of this built heritage is the skillful articulation of urban, architectural and landscape scales, specific to each operation. Considering the large area of the dwelling's lands, the architects were able to organize the volumes and to distribute the apartments relatively freely, according to the most favorable orientations on site; likewise, they could also structure the whole in an independent constructive plot. Accordingly, these works exemplify an excellent symbiosis of the industrialization of constructive processes de- 
signed aboveground, the modern urban forms arising from a free arrangement of independent objects in the space, and the attempt to rationalize the interior ways of living.

To assess the appropriateness of these hypothesis, we have conducted a pre-statistical analysis on 13 examples taken in the corpus, looking for design parameters related to sunlight. Based on the hypothesis that sunlight was a main design parameter in the urban theories of the early twentieth century (Siret 2013), which were widely spread among architects, this work aims to better understand the role of sunlight in the organization of blocks, apartments and architectural solutions. This work started with a study of historic and current sources describing the overall shape in order to enrich the database in a progressive plan: project $>$ building $>$ facade. From the total corpus, the research methodology has been already tested in 13 projects, for a total of 112 buildings and 492 facades.

For this analysis, each facade constituted an item that was characterized by parameters regarding the building shape (length, height, orientation), apartments (crossing typology, main rooms functions), architectural devices (presence of balconies, loggias, passageways, other openings). We completed the characterization with sunlight indicators resulting from simple analysis of surfaces ratios, sun path diagrams and elemental digital models. These indicators include: facade length ratio compared to the building perimeter, percent- age of glazed surface, facade openness to sunlight according to facade length and the percentage of glazed surface, percentage of facade in the building shading mask at midday December 21 and sunshine hours potential. Such indicators allowed us to understand the coherence between the architects' discourse and the projects materialization. For instance, by multiplying the "facade length ratio" and the "percentage of glazed surface", we obtain the indicator of "facade openness" that highlights the prevalent facade of a building in terms of sunlight exposure. Lastly, we conducted detailed simulations of the 13 projects aiming at analyzing the impact of shadow casting for the public space (see Figure 1).

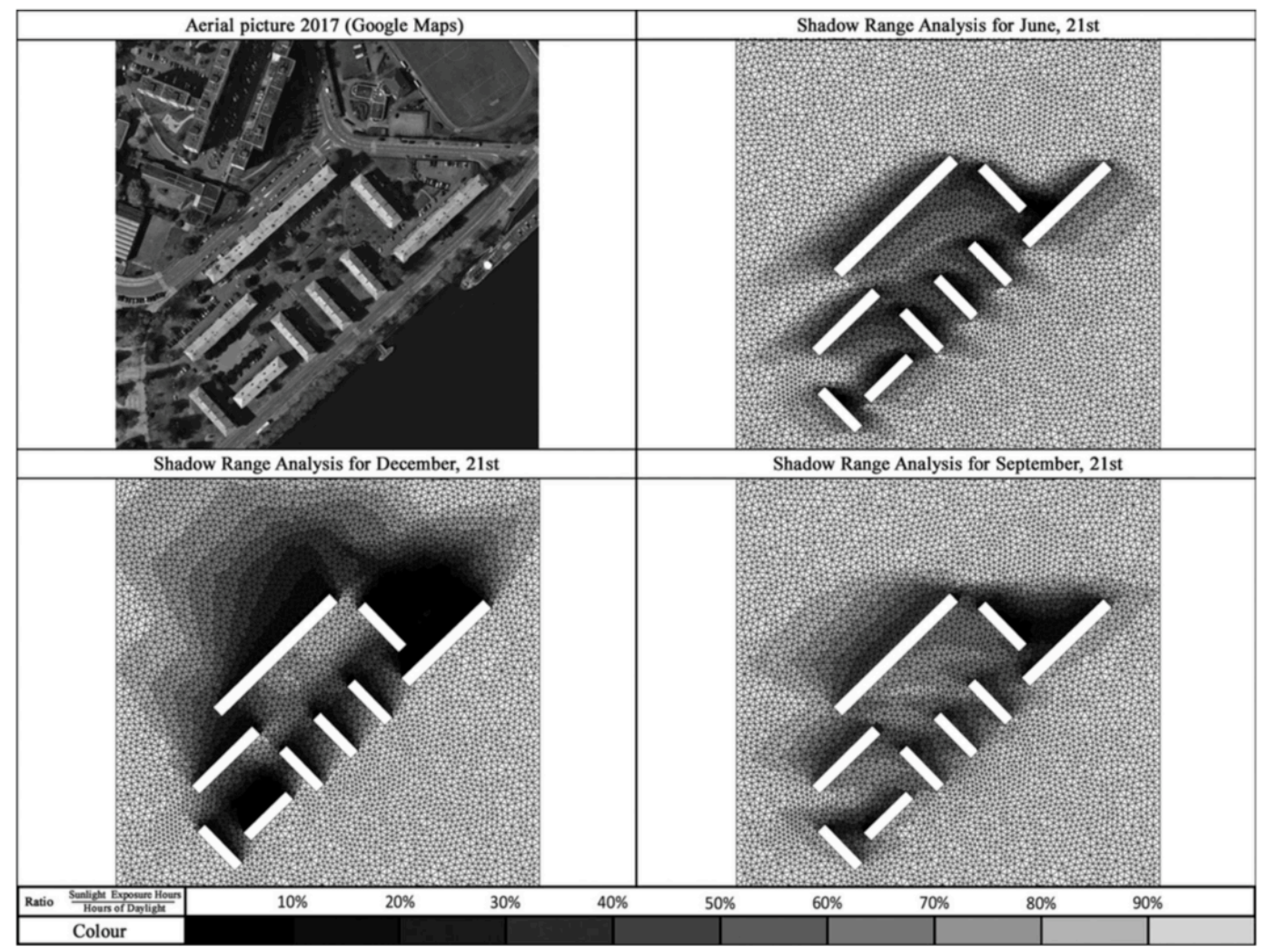

Figure 1. Esplanade Quarter in Strasbourg, France, Charles Gustave Stoskopf architect, 1951. Cumulative shading analysis in June, September and December. Values computed with T4SU Plug-in for SketchUp. (C) AAU/CRENAU.

The results of this study show three main conclusions. Firstly, the analysis of the orientations reveals a diversity of approaches that do not correspond to the more purist urban theories of sunlight in the early twentieth century (e.g., all facing South, East-West); indeed, the cardinal points are scarcely represented in the statistics. 
The main trend shown in the analysis is a preference for diagonal orientations (SE-NW or NE-SW) that represent around $70 \%$ of the cases. More surprisingly, such distribution remains stable when we pay attention to the facades with a high "openness to sunlight" indicator. These facades rarely face the cardinal points, and, again, they mainly face diagonal orientations, including those facing northern orientations. This result means that compromise approaches to sunlight with diagonal orientations were preferred to the purist urban theories on sunlight for mass housing construction in the analyzed period.

Secondly, the study of architectural devices theoretically related to sunlight control (loggias, balconies) shows that they do not mainly face orientations where they are supposed to operate correctly, which is to say close to the South. Paradoxically, loggias and balconies mainly face to the North, NNW for loggias and WNW for balconies, even if orientations close to the South are also possible. This fact reveals that sunlight control was not the primary goal of such devices; rather, they were mostly designed like outside extensions of indoor living spaces and as a part of the modernist architectural expression.

Lastly, through the study of the function of the rooms located against the facade, we notice that the orientation of living rooms is almost identical to those of the bedrooms, whereas the orientation of kitchens is close to those of the bathrooms. However, none of these functional groups shows a prevailing orientation, all of them being distributed in the four diagonal orientations aforementioned for the facades.

Solar orientation is not the only question to design the ground plan. Consequently, we have to reintroduce these problems into a larger historical context.

\section{Mass housing values in an historical perspective}

Our state-of-the-art shows that existing studies on the grands ensembles in France have mainly emphasized the industrial and technical aspects of this architecture. Considered only as a "statistical architecture" (Vayssiere 1988) in its urban and constructive sides, several research studies tend to show that the forms, the organization of blocks and the aesthetics developed are mainly at the service of a statistical necessity, without considering the implementation site (Fortin 2011). Other works highlight more the link between mass housing and the major steps of normative and political evolutions during this period (Le Goullon 2014). For a long time discarded for ideological reasons from the general history of architecture (Canteux 2014), the double process of material transformation and public appropriation leads to reconsider these objects in new perspectives. The SMART FRENCH research project makes it possible to cross-historical and social analyses with technical and material studies.

Thus, our database enables us to identify and highlight a certain number of actors and to also consider their cultural backgrounds, giving some unpublished keys to understanding this production. Indeed, these architects have all gone through a prestigious academic training in the workshops at the famous Ecole des beaux-arts, often during the inter-war period (Crosnier-Leconte 2017). They are therefore often imbued with a specific culture related to the classical art of composition (Lucan 2009) applied to theoretical projects of a very different nature and fueled by a classical culture.

Among these actors, it is interesting to note that some choose to complete their training outside the school, notably at the Institut d'Urbanisme de Paris, especially with Pierre Lavedan (1885-1982) as a professor. Besides, despite the distance taken from the Modern Movement by the School of Fine Arts, many students seek to know and appropriate the theories of the great masters, including Le Corbusier in addition to their academic training. This has been clearly demonstrated concerning the career of the important architect Jean Dubuisson (1914-2011) (Guillerm 2015). However, this is also the case of the architect Xavier Arsène-Henry (ArseneHenry 1999), whose career and production, particularly in Bordeaux, attest to this double anchoring in academic culture and modern influences. With our database, we can analyze this kind of aspects more broadly, through the biographical aspects as discourses published in specialized journals by architects, and also through the forms themselves.

To conceive and construct mass housing estates after World War II, the art of academic composition is associated with an opening, perhaps sometimes quite limited, to the theories and forms advocated by the modern movement. Thus, Gustave Stoskopf (1907-2004) (Bolle 2017) re-injects mainly his academic and classical culture in some aspects of the master plans of housing estates he designed. He particularly insisted on the creation of central squares and major visual axes. However, a certain degree of openness to modern theories 
and innovative technical devices is attested both by historical investigations and by the fine analysis of urban dispositions, and it confirms the reading made by the environmental and technical analyses.

This historical look at the cultural background of the actors can be extended to other important stakeholders of this period. The work carried out about SCIC company (Landauer 2010), a subsidiary of Caisse des Dépôts, the public bank, at the origin of important housing estates such as Sarcelles and Créteil, shows that these managers have imported many concepts and technical devices developed in the USA or in England, such as neighborhood unit's principle (Janniere 2008). The SCIC and its leader, Léon Paul-Leroy (1915-2001), an ingénieur des Ponts et Chaussées, organized many study trips in search of alternatives forms of urbanization to oppose it to the model of classical suburbs with individual housing. SCIC-related architects travelled to the USA and also in the eastern and northern countries of Europe (Bolle 2017), and they imported exogenous and innovative models to renew French suburbs. Some architects borrowed discoveries from trips across the Atlantic like the architect Marcel Lods (1891-1978) (Uyttenhove 2009). Therefore, if the mass housing in France is a very specific form, it is also the result of exchanges and cultural transfers crossing national borders.

The cultural history, the architectural and urban analysis of the forms themselves and, finally, the technical analysis of objects, seem to indicate a much more complex and nuanced reality about mass housing. Our method of research in the SMART FRENCH project reveals new aspects, and specifically an existing consideration of environmental and contextual issues by architects and stakeholders of this important period of urban and construction history.

Moreover, we assume that our method could be developed on a bigger scale. The difficulty comes from data, which are not as available in architecture as in demography or economy. But nowadays, databases on open source have been developed. For example, ground plans can be found in vector drawing format on Openstreetmaps. With a short programming, we could imagine testing solar orientations on hundreds of situations. In history, we should be also able to mobilize data of the French Mérimée base (heritage preservation) or biography of architects (Archipedie or Agorha). Hypotheses on designing ground plans could be verified in many situations.

\section{References}

Bourillon, Florence, Fourcaut, Annie, and Vadelorge Loic (Eds). 2006. "Villes nouvelles et grands ensembles." Histoire urbaine, $\mathrm{n}^{\circ} 17$ (December 2006).

Alexandroff, Georges, and Alexandroff, Anne-Marie. 1982. Architectures et climats: soleil et énergies naturelles dans l'habitat. Paris: Berger-Levrault.

APUR. 2009. Etude sur la performance énergétique des logements parisiens. http://www.apur.org/etude/analyseperformance-thermique-logements-parisiens

Arsene-Henry, Xavier. 1999. Rentrons, il se fait tard: le long chemin d'un architecte 1919-1998. Paris: L'Harmattan.

Blanchon, Bernadette, et al. 2010. Le paysage dans les ensembles urbains de logements de 1940 à 1980. Paris: Direction générale des patrimoines. 7 vol.

Bobette, Adam, Borasi, Giovanna, Russel, Harriet, and Zardini Mirko. Désolé, plus d'essence: l'innovation architecturale en réponse à la crise pétrolière de 1973. Montréal: Centre Canadien d'Architecture.

Bolle, Gauthier. 2017. Charles-Gustave Stoskopf, architecte. Les Trente Glorieuses et la réinvention des traditions. Rennes: Presses Universitaires de Rennes.

Canteux, Camille. 2014. Filmer les grands ensembles: villes rêvées, villes introuvables. Paris: Créaphis.

Carrie, Benoît, and Labrunye, Raphäl (Eds). 2015. Étude de 10 ensembles de logements construits de 1945 à 1975. Paris: Ministère de la Culture. 10 vol.

Chaunu, Pierre. 1978. Histoire quantitative, histoire sérielle. Paris: Librairie Armand Colin.

Collectif. 2011. Le guide ABC - Amélioration thermique des Bâtiments Collectifs construits de 1850 à 1974. Paris: EDIPA.

Collectif. 1995-1997. Les grands ensembles d'habitation et leur réhabilitation (1952-1992). Rapport de recherche. Paris: Ministère de l'aménagement du territoire. 2 vol.

Croizé, Jean-Claude. 2009. Politique et configuration du logement en France (1900-1980). Mémoire pour l'habilitation à diriger des recherches, Université de Nanterre.

Crosnier-Leconte, Marie-Laure. 2017. Dictionnaire en ligne des élèves architectes de l'École des beaux-arts (1800-1968). http://www.purl.org/inha/ agorha/002/83179 
Delemontey, Yvan. 2015. Reconstruire la France. L'aventure du béton assemblé, 1940-1955. Paris: Editions de la Villette.

Diener, Amandine. 2017. L'enseignement de l'architecture à l'Ecole des beaux-arts au XXe siècle, une lecture des règlements et de la pédagogie (1863-1968). Thèse de doctorat en histoire de l'architecture, Université de Strasbourg.

Dufaux, Frédéric, and Fourcaut, Annie (Eds.).2004. Le monde des grands ensembles. Paris: Créaphis.

Fortin, Jean-Patrick. 2001. Grands ensembles, l'espace et ses raisons. Paris: PUCA.

Gandemer, Jacques, and Guyot, Alain. 1976. Intégration du phénomène vent dans la conception du milieu bâti: guide méthodologique et conseils pratiques. Paris: Direction de l'aménagement foncier et de l'urbanisme (DAFU).

Giedion, Sigfried. 1929. Befreites Wohnen, Licht, Luft. Zürich: Orell Füssli.

Graf, Franz. 2012. "La cité du Lignon 1963-1971." Patrimoine et architecture, Hors-série, janvier 2012.

Gruet, Stéphane, and Papillault, Rémi. 2013. Le Mirail, mémoire d'une ville, histoire vécue du Mirail de sa conception à nos jours. Toulouse: Poiesis.

Guillerm, Elise. 2015. L'architecte Jean Dubuisson (1914-2011). Le dessin à l'épreuve des usages. Thèse de doctorat en histoire de l'art, Université Paris 1.

Jambard, Pierre. 2008. Un constructeur de la France du XXe siècle. La Société Auxiliaire d'Entreprise (SAE) et la naissance de la grande entreprise française de bâtiment (1924-1974). Rennes: Presses universitaires de Rennes.

Janniere, Hélène. 2008. "Planifier le quotidien. Voisinage et unité de voisinage dans la conception des quartiers d'habitation en France (1945-1965)," Strates, N 14.

Klein, Richard (Ed.). 2014. La cité de l'étoile à Bobigny, Candilis, Josic, Woods, un modèle de logement social. Paris: Creaphis.

Lambert, Guy, Nègre, Valérie, Gallo, Emmanuelle, and Rodriguez-Tome, Denyse. 2009. Ensembles urbains, 19401977, Les ressorts de l'innovation constructive. Paris: Direction de l'architecture et du Patrimoine.

Landauer, Paul. 2010. L'invention du grand ensemble. La Caisse des dépôts maître d'ouvrage. Paris: Editions Picard.

Le Goullon, Gwenaëlle. 2014. Les Grands ensembles en France. Genèse d'une politique publique (1945-1962). Paris; CTHS Histoire.

Carré, Dominique. 2011. Les grands ensembles, une architecture du XXe siècle. Paris: Ministère de la Culture et de la Communication.

Lucan, Jacques. 2009. Composition, non-composition: architecture et théories, XIXe-XXe siècles. Lausanne: Presses polytechniques et universitaires romandes.

RAGE. 2012. Retours d'expériences dans les bâtiments à basse consommation et risques de non-qualité, résultats 2011. Programme d'accompagnement des professionnels Règles de l'Art Grenelle Environnement (RAGE). http://www.reglesdelart-grenelle-environnement-2012. fr/regles-de-lart/detail/rapport-2011-de-letude-rex- bbcrisques.html

Sidler, Olivier. 2007. Rénovation à basse consommation d'énergie des logements en France. Projet RENAIS-

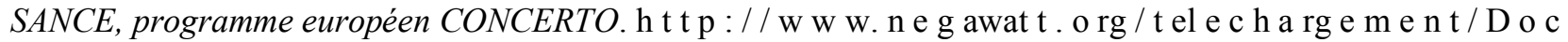
s / Sidler\%20Renovation\%20final\%201107.pdf

Siret, Daniel. 2013. "Rayonnement solaire et environnement urbain: de l'héliotropisme au désenchante-ment, histoire et enjeux d'une relation complexe". Développement durable et territoires, Vol. 4, N².

Uyttenhove, Pieter. 2009. Marcel Lods: action, architecture, histoire. Paris: Verdier.

Vayssiere, Bruno. 1988. Reconstruction-Déconstruction. Le hard french ou l'architecture française des trente glorieuses. Paris: Picard.

Voldman, Danièle. 1997. La reconstruction des villes françaises de 1940 à 1954: histoire d'une politique. Paris: l'Harmattan. 